\title{
O INSTITUTO DA USUCAPIÃO EXTRAJUDICIAL COMO FORMA DE DESJUDICIALIZAÇÃO DE DEMANDAS
}

\section{ARTIGO ORIGINAL}

SILVA, Elaine Apolinario De Amorim ${ }^{1}$

SILVA, Elaine Apolinario De Amorim. $\mathbf{O}$ instituto da Usucapião Extrajudicial como forma de desjudicialização de demandas. Revista Científica Multidisciplinar Núcleo do Conhecimento. Ano 05, Ed. 10, Vol. 09, pp. 56-90. Outubro de 2020. ISSN: 24480959, Link de acesso: https://www.nucleodoconhecimento.com.br/lei/usucapiaoextrajudicial

\section{RESUMO}

O trabalho tem o objetivo de abordar o instituto da usucapião extrajudicial, que foi trazido ao ordenamento jurídico através do Novo Código de Processo Civil de 2015, sob a ótica da desjudicialização de demandas. O método científico a ser aplicado é o dedutivo, analisando de uma forma geral o direito de propriedade e o instituto da Usucapião no Brasil, o processo de desjudicialização no Brasil, e até o processamento da usucapião extrajudicial nas serventias extrajudiciais. O referencial teórico do trabalho, será desenvolvido através de pesquisa bibliográfica, pesquisando a doutrina e legislação sobre o tema. O trabalho foi dividido em três capítulos. No primeiro, buscou-se abordar sobre os aspectos gerais do instituto da usucapião no ordenamento jurídico, abordando sobre as suas espécies, e os requisitos legais de cada uma. No segundo capítulo fez uma abordagem a respeito da desjudicialização como maneira alternativa de solução de conflitos. No terceiro capítulo fez uma

${ }^{1}$ Especialista em Direito Notarial e Registral com capacitação para o ensino no Magistério Superior pela Faculdade Damásio; Graduada em Administração UNICFaculdade de Cuiabá. Graduanda em Direito (Uninassau- Caruaru/PE); Especializando em Direito e Negócios Imobiliários pela Faculdade Damásio. 
abordagem sobre o instituto da Usucapião Extrajudicial no novo Código de Processo Civil, bem como se dá o processamento perante o oficial registrador imobiliário.

Palavras-chave: Desjudicialização, Usucapião Extrajudicial, novo código de processo civil.

\section{INTRODUÇÃO}

Diante da morosidade da tutela jurisdicional aos cidadãos, a desjudicialização surge como um instrumento para a redução de quantidade de processos na justiça, e como um meio alternativo de alcançar a efetividade de Direitos.

O código de processo civil (A Lei no 13.105, de 16 de Março de 2015), contribuiu de maneira significativa para a solução alternativa de demandas. A previsão no ordenamento jurídico do processamento do instituto da usucapião Extrajudicial pela via extrajudicial, impactou de forma positiva o cenário jurídico brasileiro.

É notório que o Brasil vivencia um momento em que o processo de desjudicialização de demandas é fomentado, crescendo nos últimos anos. Iniciou-se com a Lei no 9.514/97, que instituiu a alienação fiduciária de bem imóvel. Depois foi avançando com a Lei no 10.931/2004, que trata da Retificação Extrajudicial, que visa maior celeridade nos procedimentos de retificação registral imobiliária, transferindo essa atribuição, do poder judiciário para a esfera extrajudicial, ou seja, para o registrador imobiliário, solidificando então a sua autonomia funcional.

Depois, com o advento da Lei 11.441/07, outras mudanças importantes contribuíram sobremaneira para esse processo de desjudicialização, pois possibilitou que divórcios, separações e inventários fossem realizados nos cartórios extrajudiciais, contribuindo para o desafogamento da esfera judicial.

O código de processo Civil através do artigo ํㅜ 1.071, que inseriu na Lei oㅡ 6.015/197 (Lei dos registradores), o artigo 216-A, trazendo ao ordenamento jurídico a previsão da usucapião extrajudicial. Essa normativa é outro avanço do processo de desjudicialização de demandas, sendo relevante nesse processo. 
No primeiro momento, no capítulo 1 será analisado de uma forma geral, os aspectos do Instituto da Usucapião no ordenamento jurídico, definindo conceitos, no capítulo 2 será realizado uma investigação sobre a desjudicialização no Brasil, dos casos em que não há litígios e que é facultado a resolução pela via extrajudicial. Por fim, no capítulo 3, será abordado o instituto da Usucapião Extrajudicial da Propriedade Imobiliária, os requisitos e procedimentos e como o Instituto contribui para a desjudicialização de demandas, bem como a legislação pertinente.

A presente pesquisa bibliográfica se propõe a apresentar o que diz o ordenamento jurídico brasileiro sobre o tema, e pretende demonstrar que no Brasil os Serviços Notariais e de Registros contribuem diretamente para a desjudicialização de demandas.

O Direito evolui de acordo com as demandas exigidas pela sociedade. Assim percebese, que com as novas mudanças trazidas Código de Processo Civil, se tornou possível uma maior participação nesse processo de desjudicialização, pois com uma ata notarial lavrada por tabelião atestando o tempo de posse no imóvel usucapiendo, é possível o processamento do Instituto da Usucapião da propriedade Imobiliária diretamente perante o Registro de imóvel da localidade do Imóvel usucapiendo.

Com o sistema judicial abarrotado com a crescente demanda a cada dia, se faz necessário encontrar soluções alternativas. Com o processamento da Usucapião perante e Registrador Imobiliário, a sociedade tem uma prestação de serviços com maior eficiência, e menor tempo, em detrimento do Poder Judiciário, obtendo-se celeridade com a mesma segurança jurídica.

A problemática do presente trabalho é apresentar como o Instituto da Usucapião Extrajudicial da Propriedade imobiliária pode contribuir para a desjudicialização de demandas, e identificar os problemas mais frequentes para a tramitação do instituto pela via extrajudicial. A hipótese levantada para a solução do problema pode ser uma padronização dos procedimentos pela Justiça Estadual, publicando provimentos que pormenorize os procedimentos o quanto possível. 
Para atingir o objetivo geral, buscar-se-á alguns objetivos específicos. Apresentar o tema sob o enfoque do ordenamento jurídico brasileiro; Apresentar as Serventias Extrajudiciais como alternativas de resolução de problemas, visando a efetividade de direitos reais e eficiência;

O método científico a ser aplicado é o dedutivo, que parte de argumentos gerais para argumentos particulares, tendo como questão fundamental a relação lógica que deve ser estabelecida entre as proposições e as conclusões. Desenvolver-se á o referencial teórico do trabalho, através de pesquisa bibliográfica, pesquisando a doutrina e legislação sobre o tema.

A metodologia jurídica adotada é o historicismo crítico, tendo como fonte principal de interpretação o Direito Positivo, reconhecendo que há influência cultural sobre o conhecimento, valorizando a interpretação teleológica, ou seja, a intenção da lei. A dogmática jurídica será a transmissão de tema sobre os aspectos técnicos aos práticos do direito.

\section{ASPECTOS GERAIS DA USUCAPIÃO}

Para uma melhor compreensão do tema proposto, faz-se necessário um breve relato a respeito do instituto da usucapião no nosso ordenamento jurídico, de forma geral, bem como sobre alguns aspectos o direito real de propriedade, que tem relação com o instituto, e que é inerente ao sistema de registro de imóveis no Brasil.

\subsection{DIREITO REAL DE PROPRIEDADE IMOBILIÁRIA}

O código civil de 1916, trouxe ao direito de propriedade um caráter absoluto, onde o proprietário poderia fazer o que quisesse com a propriedade, sem nenhuma limitação, e sem que o estado fizesse qualquer intervenção. Ao longo dos anos, mediante a evolução da sociedade, mais precisamente com o código civil de 2002, o direito de propriedade passou a sofrer certas limitações, sendo uma relação de direitos e de deveres. 
A Constituição Federal de 1988 no art. 5o, XXII e XXIII, consagrou o direito de propriedade como um direito fundamental da pessoa humana, e trouxe a previsão do princípio da função social da propriedade.

Art. 50 Todos são iguais perante a lei, sem distinção de qualquer natureza, garantindo-se aos brasileiros e aos estrangeiros residentes no País a inviolabilidade do direito à vida, à liberdade, à igualdade, à segurança e à propriedade, nos termos seguintes:

XXII - é garantido o direito de propriedade;

XXIII - a propriedade atenderá a sua função social; (BRASIL, 2020)

A propriedade é uma garantia inviolável da pessoa humana, todavia deve ser exercida conforme as finalidades sociais e econômicas, sendo voltada para atender o interesse social, o bem comum, que é a sua principal função.

O código civil de 2002, trouxe um rol dos direitos reais. Em seu artigo 1.125, o direito real de propriedade está elencada entre os direitos reais. Traz ainda o Código Civil de 2002, no artigo 1.228, considerações importantes sobre a propriedade, (BRASIL, 2020):

Art. 1.228. O proprietário tem a faculdade de usar, gozar e dispor da coisa, e o direito de reavê-la do poder de quem quer que injustamente a possua ou detenha.

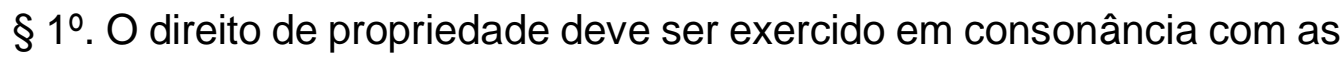
suas finalidades econômicas e sociais e de modo que sejam preservados, de conformidade com o estabelecido em lei especial, a flora, a fauna, as belezas naturais, o equilíbrio ecológico e o patrimônio histórico e artístico, bem como evitada a poluição do ar e das águas.

$\S 2^{\circ}$ São defesos os atos que não trazem ao proprietário qualquer comodidade, ou utilidade, e sejam animados pela intenção de prejudicar outrem.

§ $3^{\circ}$ O proprietário pode ser privado da coisa, nos casos de desapropriação, por necessidade ou utilidade pública ou interesse social, bem como no de requisição, em caso de perigo público iminente.

§ $4^{\circ}$ O proprietário também pode ser privado da coisa se o imóvel reivindicado consistir em extensa área, na posse ininterrupta e de boa- 
fé, por mais de cinco anos, de considerável número de pessoas, e estas nela houverem realizado, em conjunto ou separadamente, obras e serviços considerados pelo juiz de interesse social e econômico relevante.

§ 5ํ№ caso do parágrafo antecedente, o juiz fixará a justa indenização devida ao proprietário; pago o preço, valerá a sentença como título para o registro do imóvel em nome dos possuidores.

De acordo com o art. 1128 caput, podemos definir a propriedade, como um direito real, que confere ao proprietário as faculdades de servir-se da coisa, explorar economicamente, podendo escolher a destinação a ser dada ao bem, e reivindicar a coisa.

O direito real de propriedade tem caráter erga omnes, pois é oponível a todos. É um direito subjetivo, e tem na estrutura os elementos: sujeito ativo, sujeito passivo, objeto, e a relação jurídica.

\subsubsection{A AQUISIÇÃO DA PROPRIEDADE IMOBILIÁRIA}

No ordenamento jurídico brasileiro, a aquisição da propriedade imobiliária pode acontecer de forma originária ou derivada.

Acontece de forma originária quando não há vínculo de transferência da coisa de uma pessoa para outra, portanto não há transmissão. A usucapião, é uma forma originária de aquisição, visto que o possuidor não adquire o bem de outro, mas adquire em razão da posse.

Outro caso de aquisição originária é a desapropriação, pois o estado não adquire o bem em razão da vontade do proprietário, mas sim por ser uma obrigatoriedade, ele não compra, e sim incorpora ao seu patrimônio, pagando apenas uma indenização, e não o preço que o proprietário estipular. A acessão também é uma forma originária de aquisição.

A aquisição de forma derivada, ocorre quando há uma transmissão da coisa, por ato inter vivos ou causa mortis, há uma manifestação de vontade, o proprietário transfere 
a outrem, portanto há uma relação jurídica entre as pessoas, e pode ser gratuita ou onerosa.

\subsubsection{MODOS DE AQUISIÇÃO DA PROPRIEDADE IMOBILIÁRIA}

Há vários modos de adquirir a propriedade imobiliária. De acordo com o código civil de 1916 essas formas são a Sucessão, Usucapião, Acessão e Transcrição.

O Código Civil de 2002, não trouxe de forma muito organizado as formas de aquisição da propriedade imobiliária. Mas prevê que a desapropriação, a adjudicação compulsória e o casamento pela comunhão universal são modos de aquisição da propriedade.

De acordo com a doutrina os modos de aquisição são: a usucapião, registro de título aquisitivo, acessões. Há quem defenda que também são modos de aquisição as sucessões, as desapropriações, as adjudicações compulsórias, e o casamento pela comunhão universal de bens.

A usucapião é modo originário de aquisição, e o ocupante adquire a propriedade através do tempo prolongado do exercício da posse de forma mansa e pacífica. Há no ordenamento jurídico várias espécies de usucapião.

O registro do título aquisitivo é uma forma derivada de aquisição. São exemplos de título aquisitivo, a compra e venda, a doação, troca, dação em pagamento, etc.

A acessão, é quando um patrimônio tem ganho, aumentando o seu tamanho. Está previsto no art. 1.248 do Código civil. Podem ser por formação de ilhas; por aluvião; por avulsão; por abandono de álveo; por plantações ou construções.

A sucessão é quando há aquisição através por sucessão legítima, por testamento, por legado. 


\subsection{BREVE RELATO HISTÓRICO DA USUCAPIÃO NO BRASIL}

A usucapião é um instituto muito antigo, que tem o condão de conceder o direito de propriedade ao possuidor da coisa, por intermédio do exercício da posse. Não se sabe ao certo a data do surgimento deste instituto. Alguns autores afirmam que surgiu na Grécia, outros afirmam que foi através do direito Romano, em especial as Leis das XII tábuas. Sobre o surgimento desse instituto, Barrufini (BARRUFINI, 1998, p.21) dispõe:

Apesar de boa parte dos doutrinadores entenderem que a usucapião tenha tido sua origem em Roma, remontando às Leis da XII Tábuas, também outros entendem que a usucapião foi gerada pela inteligência grega [...]. Luiz da Cunha Gonçalves, se que no mesmo diapasão, deixando implícito, quando discorre sobre a usucapião dos romanos, que a verdadeira formulação ocorreu em terras helênicas.

A usucapião é uma forma originária de adquirir a propriedade por meio do exercício da posse de forma prolongada, pública e pacífica, portanto é uma apropriação da posse por um certo tempo. Ao longo do tempo, com a civilização, esse instituto ultra milenar, foi se aprimorando, e adequando às necessidades da sociedade.

A lei das XII tábuas, previa que o proprietário perdia a propriedade através da prescrição do direito da propriedade, ou seja, pela sua inércia na propriedade. O prazo era de dois anos para propriedades imóveis, e de um ano para as propriedades móveis.

A usucapião é uma forma originária de aquisição, portanto para a lei não há necessidade saber quem é o proprietário, o possuidor em maioria das vezes não adquire a coisa do proprietário. A usucapião garante a propriedade através da posse continuada.

Esse instituto no ordenamento jurídico Brasileiro teve influência lusitana, e do Direito Romano. Tal influencia se dá em decorrência da colonização portuguesa que ao descobrir o território do Brasil, adquiriu o título de posse. A partir dessa descoberta, com o intuito de povoar o território, faziam doações de terras através das cartas de sesmarias, visando incentivar o cultivo dessas terras. Esse sistema de ocupação do 
território por meio do exercício da posse, sem nenhum registro das terras se deu até a independência do Brasil no ano de 1.822, quando começaram a surgir os registros das terras de maneira ainda muito precária.

A lei no 601 de 1.850, conhecida como a lei do vigário ou lei de terras, foi um marco importante para o instituto, que previa uma legitimação de posse das terras pelo vigário da igreja católica, visando facilitar a exploração dessas terras. Porém ainda era uma legitimação muito tímida, pois faltava recursos para a medição das terras.

Depois, com a lei orçamentária n 317/1.843 criou-se um controle do crédito, com o registro das hipotecas, estabelecendo normas para as garantias para financiamentos para cultivar as terras.

Mais adiante, foi promulgada a lei ำ $1.237 / 1864$, denominada lei do Registro geral de imóveis, que buscava a formalidade da transcrição, para que os credores tivessem conhecimento da situação das terras oferecidas em garantia. A lei previa que a transcrição não induzia prova de domínio, que ficava a salvo quem for, ou seja, com a posse prolongada, a usucapião.

O código civil de 1.916 avançou em muitos aspectos, saneou algumas questões, e trouxe o princípio que prevê que a propriedade só se adquire com o registro, também consolidou o sistema de registro de imóveis vigente no Brasil, que é um sistema de presunção relativa.

No tocante à usucapião previu os requisitos de qualidade da posse, tempo, ânimo de dono, pacificidade, continuidade, ininterrupção e publicidade. Instituiu duas modalidades de usucapião, a extraordinária e a ordinária. A partir do código civil de 1.916, esse instituto evoluiu na medida que a legislação foi avançando, vejamos as palavras de Hélio Vianna (VIANNA, 1972, p.34):

No Código Civil, que entrou em vigor a partir de 1916, regularam-se as normas de aquisição e transmissão de bens imóveis, inclusive a aquisição do domínio pelo Usucapião (sic). Em 1938, criou-se, no Ministério da Agricultura, a Divisão de Terras e Colonização. Em 1954, o Instituto Nacional de Imigração e Colonização. Novos 
aspectos assumiram o problema das terras a serem aproveitadas, no Brasil, depois da Revolução de 1964: criaram-se os Institutos, Nacional de Desenvolvimento Agrário (INDA) e o Brasileiro de Reforma Agrária (IBRA). Unificados, em 1970, no Instituto Nacional de Colonização e Reforma Agrária (INCRA), ao qual estão afetas questões de aproveitamento de terras, no Brasil [...]

No artigo 550, o código civil de 1.916, trouxe a usucapião extraordinária que previa um tempo de trinta anos de exercício da posse no imóvel pelo ocupante, para ter o reconhecimento da usucapião através da justiça, que mais tarde, passou para vinte anos, e atualmente prevê um prazo de quinze anos, podendo em alguns casos ser reduzida para dez anos.

O código civil de 1.916, no artigo 551, trouxe a previsão da usucapião ordinária, que constava um tempo de exercício de posse de quinze anos entre ausentes, e de dez anos entre presentes, comprovando a posse mansa e pacífica, e também a boa fé e justo título.

Ao longo do tempo, esse instituto foi se moldando à sociedade e evoluindo, reduzindo os prazos, e com a promulgação da constituição federal de 1.988, criou-se várias modalidades de usucapião, que abordaremos adiante.

\subsection{CONCEITO DE USUCAPIÃO}

Usucapião é uma forma de garantir o direito de propriedade de um determinado bem por meio da posse - posse qualificada - por um período.

O ordenamento jurídico brasileiro permite a usucapião de bens móveis e de bens imóveis. O mais comum é o de bens imóveis, embora juridicamente seja possível usucapir um bem móvel, no Brasil não tem muita aplicabilidade a usucapião de bens móveis.

Podemos extrair do artigo 1.238 caput do Código Civil/2002 (BRASIL, 2020), uma definição geral de usucapião, "Art. 1.238. Aquele que, por quinze anos, sem interrupção, nem oposição, possuir como seu um imóvel, adquire-lhe a propriedade, independentemente de título e boa-fé". Em consonância com o dispositivo, a posse 
precisa ser mansa e pacífica, ou seja, não pode ser uma posse violenta. A posse tem que ser pública, reconhecida por vizinhos e por outros, como se fosse o dono do bem.

O autor Arnaldo Rizzardo (RIZZARDO, 2013, p. 264), conceitua o instituto da usucapião da seguinte forma:

\section{$[\ldots]$}

um modo originário de aquisição, pelo qual a pessoa que exerce a posse em um imóvel, por certo prazo previsto em lei, adquire-lhe o domínio, desde que sua posse tenha satisfeito certos requisitos, ou seja, revele que sempre foi pacífica, mansa e ininterrupta, sem oposição alguma do titular do domínio e com o animus domini.

O exercício da posse por um lapso temporal é requisito elementar da usucapião. Ainda conceituando o instituto da usucapião, o autor Orlando Gomes (GOMES, 2012, p. 180) escreve:

Usucapião é, no conceito clássico de Modestino, o modo de adquirir a propriedade pela posse continuada durante certo lapso de tempo, com os requisitos estabelecidos em lei: usucapio est adjectio domini per continuationem possessionis temporis lege definit.

Conforme os conceitos apresentados pelos autores, vejamos que para que o possuidor adquira a propriedade é necessário que haja uma posse prolongada, e atenda aos requisitos estabelecidos para cada espécie. Orlando Gomes, entende que esses requisitos legais podem ser caracterizados como pessoais, reais e formais.

Os requisitos pessoais, podemos entender que é a capacidade civil e a legitimidade do usucapiente. Os requisitos reais, são relacionados aos bens passíveis do instituto da usucapião, pois há no ordenamento jurídico previsão de bens que não podem ser objetos de usucapião, pode-se citar a título de exemplo os bens públicos. Os requisitos formais são aqueles elementos do instituto, portanto, são a posse, o lapso de tempo e o ânimo de dono, e dependendo da espécie acrescenta o justo título e boa-fé.

De acordo com parte da doutrina, a usucapião prescinde alguns pressupostos: a) res habilis; b) possessio; c) fides; d) tempus. O pressuposto da res habilis é a que a coisa a ser usucapida deverá ser um bem que possa ser usucapido, que não haja 
impedimento. O pressuposto da possessio é a relação de posse no bem, e que seja com animus domini. Já o pressuposto o fides está previsto no artigo 1.201, parágrafo único do código civil de 2.002, se resume na boa-fé. O pressuposto tempus é o lapso temporal, que varia de acordo com o tipo de usucapião.

Usucapião é modo originário de aquisição da propriedade pelo possuidor em face da passividade geral do proprietário ou de terceiros. É uma solução para aqueles que tem o domínio sobre um imóvel por meio da posse, mas que não tem o título da propriedade.

O lapso temporal previsto para o reconhecimento da usucapião tem o condão de oferecer maior segurança jurídica ao instituto. Com a constituição de 1.988, esse instituto passou a ser um instrumento eficaz para efetivar o direito de propriedade, que é um direito fundamentação da pessoa humana.

A usucapião por constituir uma forma originária de aquisição, onde o ocupante vai adquirir o direito de propriedade por exercer uma posse prolongada, na propriedade, não havendo relação jurídica com o antigo proprietário, pois não adquire deste. Esse instituto tem o caráter aquisitivo, e extintivo. A prescrição aquisitiva ocorre em face da inércia prolongada do proprietário. A aquisitiva, pelo fato de o ocupante adquirir a propriedade através da posse qualificada. Nesse sentido Farias Rosenvald (FARIAS; ROSENVALD , 2012, p. 398-399), dispõe sobre os efeitos da usucapião:

como na usucapião, o possuidor adquire a propriedade por sua $p$ osse prolongada, a despeito de qualquer relação jurídica com o o proprietário anterior, não incidirá o fato gerador do ITBI (a transmissão da propriedade, a teor do art. 35 do CTN), já que o usucapiente não adquire a coisa do antigo proprietário, mas contra o antigo proprietário. Outrossim, se existir eventual ônus real sobre o imóvel, em razão de negócio jurídico praticado pelo antigo proprietário (v. g., hipoteca, servidão), não subsistirá 0 gravame perante 0 usucapiente, que receberá a propriedade límpida, isenta de máculas.

Dessa forma, nas aquisições fundadas no instituto da usucapião, não incidem o Imposto de Transmissão sobre bens imóveis - ITBI - pois não é uma aquisição onde 
houve transmissão, mas sim uma aquisição originária, o ocupante não adquire do proprietário, mas sim adquire em razão do exercício da posse qualificada.

\section{A ESFERA EXTRAJUDICIAL COMO ALTERNATIVA DE SOLUÇÃO DE CONFLITOS}

Ao decorrer dos anos, o Estado vem enfrentando muitos desafios para oferecer uma prestação jurisdicional eficiente a sociedade. A crescente judicialização de direitos desencadeados com a promulgação da Constituição Federal de 1988, ocasionou um aumento nas demandas processuais, nos recursos a serem julgados, aumentando também o custo dos processos às partes.

É notório a crise em que o poder judiciário está submergido, com as demandas de processos crescendo dia após dia, superdemandada e, por conseguinte, morosa, por vezes ineficiente. A prestação da tutela jurisdicional ineficácia, por vezes contribui para gerar uma insegurança à sociedade, que ficam insatisfeitos quando dependem do Estado para solucionar os conflitos. Nesse contexto a desjudicialização surge como forma alternativa de resolução de conflitos. Neste capítulo será abordado a esfera extrajudicial como solução de conflitos.

\subsection{CONTEXTUALIZAÇÃO DA DESJUDICIALIZAÇÃO}

Por muito tempo o estado se envolvia para oferecer uma resolução dos conflitos das pessoas. O poder de dizer o direito era exercido pelas partes conflitantes, através da autotutela. No Século XVII, após a teoria da repartição dos Poderes, o Estado, avocou para si esse poder, passando a ser com exclusividade o detentor do poder de aplicar e dizer o Direito.

Com a promulgação da constituição Federal de 1988, e com as mudanças trazidas ao ordenamento jurídico, em especial os princípios constitucionais fundamentais inseridos no artigo $5^{\circ}$ da carta Magma, a garantia do acesso à justiça ganhou força, pois ficou consagrada no artigo 5ํ, inciso XXXV da Constituição Federal, (BRASIL, 2020) vejamos: 
Art. 5o Todos são iguais perante a lei, sem distinção de qualquer natureza, garantindo-se aos brasileiros e aos estrangeiros residentes no País a inviolabilidade do direito à vida, à liberdade, à igualdade, à segurança e à propriedade, nos termos seguintes:

XXXV - a lei não excluirá da apreciação do Poder Judiciário lesão ou ameaça a direito;

Esse dispositivo consagrou no ordenamento jurídico o princípio da inafastabilidade da jurisdição. Sobre esse importante princípio, Alexandre de Moraes (MORAES, 1998, p. 197) esclarece:

O Poder Judiciário, desde que haja plausibilidade de ameaça ao direito, é obrigado a efetivar o pedido de prestação judicial requerido pela parte de forma regular, pois a indeclinabilidade da prestação judicial é princípio básico que rege a jurisdição, uma vez que a toda violação de um direito responde uma ação correlativa, independentemente de lei especial que a outorgue.

Esse princípio preceitua o direito à proteção jurídica através dos tribunais, de forma ampla. Canotilho defende que a garantia de acesso à justiça, representa um princípio fundamental do Estado de Direito (CANOTILHO, 2003).

Com essa avocação exclusa para o estado da tutela jurisdicional, todos que se sentirem lesados têm o direito de obter do Poder Judiciário o direito de ação de forma adequada. Com essa garantia do direito à ação, houve um incentivo à judicialização demandas. Quem antes tinha receio de litigar, agora com a garantia do estado, procura ter os seus direitos reavidos.

Com essa conquista do estado democrático de direito em 1988 percebe-se que houve um aumento das demandas judiciais. Agora o estado enfrenta desafios de como administrar essas crescentes demandas para que o poder judiciário tenha celeridade e efetividade.

A emenda Constitucional № 45/2004, acrescentou ao art. 5ำ da CF/88 o inciso LXXVIII, consagrando no nosso ordenamento jurídico o princípio da celeridade processual, vejamos "a todos, no âmbito judicial e administrativo, são assegurados a razoável 
duração do processo e os meios que garantam a celeridade de sua tramitação", esse princípio nos remete à ideia de economicidade.

Esse princípio se relaciona com o princípio da inafastabilidade da jurisdição. Se por um lado o estado avocou para si a exclusividade de dizer o direito, agora não basta oferecer a sociedade somente 0 acesso à justiça, mas se faz necessário que ofereça uma justiça com celeridade e de forma tempestiva. Nesse sentido, o autor Luiz Guilherme Marinoni (MARINONI, 1999, p. 218), escreve:

Uma leitura mais moderna, no entanto, faz surgir a ideia de que essa norma constitucional garante não só o direito de ação, mas a possibilidade de um acesso efetivo à justiça e, assim, um direito à tutela jurisdicional adequada, efetiva e tempestiva. Não teria cabimento entender, com efeito, que a constituição da República garante ao cidadão, que pode afirmar uma lesão ou ameaça a direito, apenas e tãosomente uma resposta, independentemente de ser ela efetiva e tempestiva.

Diante dos princípios da inafastabilidade da jurisdição e celeridade processual verificamos uma necessidade de se pensar novos paradigmas para o poder judiciário. Assim, compreendemos que a obrigação de oferecer uma tutela jurisdicional eficiente para a sociedade, está sobre o estado, devendo este, criar mecanismos para garantir esse direito fundamental aos jurisdicionados.

Para melhor compreensão da situação do poder judiciário, vejamos trecho do relatório divulgado pelo Conselho Nacional de Justiça (CNJ, 2016):

Tais fatores ajudam a entender porque, apesar de se verificar um número de processos baixados quase sempre equivalente ao número de casos novos, o estoque de processos no Poder Judiciário (74 milhões) continua aumentando desde o ano de 2009, conforme demonstra o Gráfico 3.24. O crescimento acumulado deste período foi de 19,4\%, ou seja, 9,6 milhões de processos a mais em relação àquele ano. Dessa forma, mesmo que o Poder Judiciário fosse paralisado sem ingresso de novas demandas, com a atual produtividade de magistrados $e$ servidores, seriam necessários aproximadamente 3 anos de trabalho para zerar o estoque. 
Essa é a situação em que se encontra o poder judiciário. O relatório afirma que mesmo que a justiça ficasse sem novas demandas, demoraria aproximadamente três anos para conseguir resolver os processos que tramitam o poder judiciário.

Diante desse cenário de tamanha morosidade na tutela jurisdicional, exploraremos, uma forma alternativa para a solução desse problema, visando uma tutela que possa efetivar os direitos.

\subsection{MEIOS ALTERNATIVOS DE SOLUÇÃO DE CONFLITOS}

O Brasil vem adotando nos últimos anos mecanismos que ajudam a reduzir o problema da morosidade instalado na justiça. Nesse tópico, será feito uma abordagem da função notarial e registral como uma alternativa na solução desse problema, em especial apresentando os atos lavrados nos Tabelionatos de Notas e nos Registros de Imóveis. Nesse aspecto Daniela Olímpio de Oliveira (OLIVEIRA, 2014, p.163), discorre sobre a desjudicialização:

A

desjudicialização está mais afeita a uma situação - o movimento de retirada de procedimentos que antes eram típicos da função judicial, sendo agora absorvidos por outras instâncias não judiciais. Em verdade, pode-se manter a coexistência dos meios, ou não. Têm-se, assim, procedimentos que são mesmo excluídos da apreciação judicial, e outros que passam a ser assumidos também pela processualidade administrativa ou cartorária.

A função notarial segundo Leonardo Brandelli (BRANDELLI, 2007, p. 04), "é uma criação social, que surgiu com a função de auxiliar em suas necessidades, conforme o desenvolvimento do mundo jurídico". Dessa forma, desempenha uma colaboração processual através da forma pública dos documentos notariais, que possuem presunção juris tantu.

O Notário é quem formaliza a vontade das partes, atuando com imparcialidade, fazendo cumprir a lei, zelando pela aplicação dos princípios que regem a atividade extrajudicial, e pela prevenção de litígios. Em contrapartida, o Registrador examina o título a ser registrado, realizando a qualificação do título de acordo com a Lei, e com 
os princípios que regem a atividade registral, verificando se o título está em conformidade, admitindo ou não o registro.

Pela via extrajudicial, a sociedade tem à disposição uma variedade de atos essenciais à vida moderna. Tais atos são prestados com celeridade e segurança jurídica, confiança e fé pública. As atividades notarial e registral estão presentes praticamente em todas as cidades brasileiras. Dessa forma, aproveitar essa estrutura para acelerar o processo de desjudicialização de demandas é muito importante.

Esse processo de desjudicialização, que compartilha com os notários e registradores a competência para solução de demandas foi impulsionado com a Lei 9.514/97, que instituiu a alienação fiduciária de bem imóvel. Depois foi avançando com a Lei $\mathrm{n}^{0}$ 10.931/2004, que trata da Retificação Extrajudicial, que visa maior celeridade nos procedimentos de retificação registral imobiliária, transferindo essa atribuição, do poder judiciário para a esfera extrajudicial, ou seja, para o registrador imobiliário, solidificando então a sua autonomia funcional.

O advento da Lei 11.441/07, trouxe mudanças importantes que contribuíram para a desjudicialização de demandas, pois possibilitou que divórcios, separações e inventários sejam realizados nos cartórios extrajudiciais, o que contribuiu para o desafogamento da esfera judicial.

O novo código de processo Civil trouxe alterações importantes de enfatizam a celeridade processual. No artigo 1071, que inseriu o artigo 216-A na Lei no 6.015/1973), que prevê a usucapião extrajudicial, é outro avanço do processo de desjudicialização de demandas, e que vem contribuindo de maneira muito positiva nesse processo.

O instituto da Usucapião é uma forma de aquisição da propriedade mediante a posse ao longo de tempo, juntamente com o atendimento de outros requisitos definidos na legislação.

Os principais atos lavrados pelos tabeliães de notas que contribuem no processo de desjudicialização de demandas são: Escritura de Inventário e Partilha, Separação e 
Divórcio, Ata Notarial. Já os principais atos praticados pelo Registrador Imobiliário são: Alienação Fiduciária de Bem Imóvel, retificação Administrativa, e Usucapião Extrajudicial da Propriedade Imobiliária.

O exemplo mais recente de desjudicialização é a usucapião extrajudicial, previsto no novo código de processo civil, que ampliou o princípio do acesso à justiça introduzindo a usucapião extrajudicial no ordenamento jurídico. Introduziu art. 216-A à lei 6.015/73.

Através desse instituto muitos casos de imóveis que estão irregulares podem ser solucionados perante o registrador imobiliário, sem necessidade de ajuizar ação, contribuindo para que haja celeridade e segurança jurídica, facilitando ao possuidor a aquisição do imóvel através de exercício da posse prolongada, pacífica, e sem interrupção.

O interessado, poderá requer ao registrador o processamento da usucapião, desde que cumpra alguns requisitos previsto na lei. É possível o processamento pela via extrajudicial, de todas as espécies existentes no ordenamento jurídico.

Faz-se necessário a representação por advogado, ata notarial atestando o tempo da posse, planta e memorial descritivo do imóvel juntamente com a anotação de responsabilidade técnica (ART) do engenheiro, certidões negativas e outros documentos.

Munido com estes documentos requer ao registro de imóveis da localidade do imóvel. O registrador ao receber o pedido, protocola, e inicia o processamento. Estando os autos em conformidade com a legislação, e não havendo litígios, nem impugnação pelos interessados, registrar-se-á o imóvel usucapiendo em nome do possuidor.

Pela relevância desse instituto, abordaremos com maior ênfase em capítulo próprio, pois é objeto deste trabalho. 


\section{PROCEDIMENTO EXTRAJUDICIAL DE USUCAPIÃO DA PROPRIEDADE IMOBILIÁRIA}

Nesse capítulo, será realizado uma pesquisa jurídica e doutrinária sobre o instituto da usucapião Extrajudicial, abordando os avanços trazidos por ele ao ordenamento jurídico. Este importante instituto permite que a propriedade imobiliária seja adquirida de forma originária pelo possuidor, através da posse contínua, pública mansa e pacífica durante certo período de tempo.

\subsection{NOÇÕES GERAIS SOBRE O INSTITUTO DA USUCAPIÃO EXTRAJUDICIAL}

Antes da vigência da Lei no Lei n. 13.105, de 2015, o novo código de processo civil, o possuidor que tivesse interesse em adquirir a propriedade através desse instituto, deveria ingressar na justiça com ação própria de usucapião, seguindo todas as regras e fases do processo. Esse procedimento via de regra se tornava muito moroso e desgastante, demandando muito tempo e custo aos interessados.

O código de processo civil trouxe a previsão da usucapião extrajudicial no art. 1.071 que acrescentou o art. 216-A à lei 6.015/73, intitulada lei dos registros públicos, onde o instrumento da usucapião passou ter caráter opcional aos interessados, pois poderá ser processado além da esfera judicial, pela via extrajudicial.

Essa previsão visa contribuir para que procedimento seja simplificado, incentivando a regularização de muitos imóveis, retirando-os da informalidade e trazendo para o mercado imobiliário, dessa forma contribuindo para a desjudicialização de demandas, reduzindo a sobrecarga de processos do poder judiciário. Nesse sentido João Pedro Lamana Paiva (PAIVA, 2015), enfatiza a simplicidade no processamento desse instituto:

[...] facilitará ao possuidor a aquisição da propriedade imobiliária fundada na

posse prolongada porque, representado por advogado e mediante requerimento instruído com uma ata notarial, planta e memorial d 
escritivo do imóvel, certidões negativas e outros documentos, apresentará 0 pedido ao registro de imóveis em cuja circunscrição esteja localizado o i móvel usucapindo, onde será protocolado, autuado e tomadas todas as providências necessárias ao reconhecimento da posse aquisitiva da propriedade imobiliária e seu registro em nome do possuidor.

Já havia a previsão no ordenamento jurídico da usucapião pela via extrajudicial, em casos de regularização fundiária urbana. Tal previsão veio com o advento da Lei $n$. 11.977, de 2009,a lei que do Programa Minha Casa, Minha Vida, que visa à regularização fundiária de assentos urbanos de áreas irregularmente ocupadas por população de baixa renda. Todavia, a sua implementação foi muito restrita, pois visa somente à regularização fundiária urbana coletiva, e o procedimento administrativo tem uma certa complexidade, o que não demonstrou muito êxito na prática.

A previsão da usucapião extrajudicial trazida pelo novo código de processo civil retira da justiça a exclusividade da regularização de posse e a questão da usucapião, ampliando o procedimento na esfera extrajudicial, sendo possível para qualquer situação consensual, e simplifica o procedimento aos interessados, tornando-o mais econômico e célere, uma vez que atividade extrajudicial garante a publicidade, autenticidade, a eficácia e a segurança jurídica aos atos praticados nessa esfera.

A previsão da usucapião pela via extrajudicial, cabe a qualquer bem imóvel que seja passível de usucapião, exceto previsão em contrário. Os imóveis que tenham ônus de inalienabilidade, bem como os bens públicos, não poderão ser objeto da usucapião extrajudicial. Outro ponto relevante é que dispensa a intervenção judicial do Ministério Público.

Embora o novo código de processo civil tenha avançado, trazendo a previsão da usucapião pela via extrajudicial, ainda havia problemas para a aplicabilidade desse instituto. O maior gargalho, estava na anuência expressa do proprietário tabular e os titulares de direitos registrados ou averbados na matrícula.

O § 2ºdo artigo 216-A da lei 6.015/73 previa que em caso de não haver a assinatura do proprietário tabular e dos titulares de direitos na planta e no memorial descritivo, o 
registrador deveria notificá-los para manifestação para dar anuência, e a não manifestação era considerada como discordância. Essa previsão se tornou uma barreira à efetividade do instituto.

Ora, se o proprietário tabular e os titulares de direitos, podem assinar a planta e memorial descritivo, ou a notificação, dando anuência, eles poderiam assinar uma escritura pública de compra e venda do imóvel, resolvendo toda a irregularidade. $\mathrm{O}$ que induz a entender é que o instituto seria válido e efetivo para aqueles, que por motivos qualquer, queiram se isentar de alguma obrigação para a lavratura da escritura de compra e venda, bem como o recolhimento do ITBI, e não àqueles que estão há tempo tentando o direito de propriedade do seu imóvel, mas ainda não adquiriram por não ser possível atender os requisitos exigidos por lei.

A maioria dos imóveis que estão na informalidade, que poderiam ser regularizados através da usucapião extrajudicial, tem o proprietário tabular desaparecido, estando em lugar incerto e não sabido, por vezes, o possuidor nem o conheceu, ou já é falecido. Dessa forma seria impossível conseguir anuência, comprometendo a aplicabilidade do instituto.

Mediante essa questão, a medida provisória ํㅡ 759, de 2016, que foi convertida na Lei ํㅜ 13.465, de 11 de Julho de 2017, trouxe a solução ao problema apresentado. Ela alterou o artigo $216-\mathrm{A}, \S 2^{\circ}$, da lei $6.015 / 73$, onde passou a prevê que o silencio seja interpretado como concordância. Essa alteração impactou positivamente aplicabilidade da usucapião extrajudicial. Vejamos o disposto no 216-A, § 2ํㅡㄹ (BRASIL, 2015):

Se a planta não contiver a assinatura de qualquer um dos titulares de direitos registrados ou averbados na matrícula do imóvel usucapiendo ou na matrícula dos imóveis confinantes, o titular será notificado pelo registrador competente, pessoalmente ou pelo correio com aviso de recebimento, para manifestar consentimento expresso em quinze dias, interpretado o silêncio como concordância.

Dessa forma, passou a admitir a anuência tácita, em caso de não haver manifestação expressa. 
Visando uma padronização, e esclarecimento de dúvidas, o conselho nacional de justiça (CNJ), publicou o provimento no 65 de 14/12/2017, onde estabelece diretrizes a serem seguidas no procedimento da usucapião extrajudicial que será abordado nesse capítulo.

\subsection{REQUISITOS}

É admitido a usucapião pela via extrajudicial em todas as modalidades previstas no ordenamento jurídico, salvo disposição legal em contrário. Há requisitos que são comuns a todas as espécies, permitida pelo ordenamento jurídico, todavia há de se observar as particularidades de cada uma, que pode requerer outros requisitos.

O artigo 216-A da lei 6.015/1973 (BRASIL, 2015), a lei dos registros públicos, que foi inserido através do artigo 1.071 do novo código de processo civil, dispõe sobre os requisitos necessários para o procedimento a usucapião pela via extrajudicial:

Art. 216-A. Sem prejuízo da via jurisdicional, é admitido o pedido de reconhecimento extrajudicial de usucapião, que será processado diretamente perante o cartório do registro de imóveis da comarca em que estiver situado o imóvel usucapiendo, a requerimento do interessado, representado por advogado, instruído com: (Incluído pela Lei № 13.105, de 2015) (Vigência)

I - ata notarial lavrada pelo tabelião, atestando o tempo de posse do requerente e de seus antecessores, conforme o caso e suas circunstâncias, aplicando-se o disposto no art. 384 da Lei no 13.105, de 16 de março de 2015 (Código de Processo Civil); (Redação dada pela Lei no 13.465, de 2017)

II - planta e memorial descritivo assinado por profissional legalmente habilitado, com prova de anotação de responsabilidade técnica no respectivo conselho de fiscalização profissional, e pelos titulares de direitos registrados ou averbados na matrícula do imóvel usucapiendo ou na matrícula dos imóveis confinantes; (Redação dada pela Lei no 13.465, de 2017)

III - certidões negativas dos distribuidores da comarca da situação do imóvel e do domicílio do requerente; (Incluído pela Lei oㅜ 13.105, de 2015)

(Vigência) 
IV - justo título ou quaisquer outros documentos que demonstrem a origem, a continuidade, a natureza e o tempo da posse, tais como o pagamento dos impostos e das taxas que incidirem sobre 0 imóvel. (Incluído pela Lei no 13.105, de 2015) (Vigência)

O artigo inicia trazendo o caráter opcional aos interessados. Não há que esgotar uma via, para ingressar na outra, ou seja, poderá ingressar tanto na via judicial, ou pela via extrajudicial, sem ter que obedecer a ordem, desde que não sejam concomitantemente.

O pedido deverá ser feito através de requerimento assinado por advogado, acompanhado de ata notarial lavrada por tabelião atestando o tempo de posse pelo possuidor no imóvel usucapiendo, bem como as circunstâncias dessa posse, que deverá ser pacífica, duradoura, ininterrupta, e pública e deverá ter ânimo de dono.

Em obediência ao princípio da territorialidade, o ofício competente para 0 procedimento é o registro de imóveis da circunscrição imobiliária onde o imóvel usucapiendo está localizado.

Também é necessário que o pedido seja acompanhado de Planta e memorial descritivo do imóvel com a devida anotação de responsabilidade técnica do engenheiro responsável, que deverá conter a assinatura do engenheiro, se possível do proprietário tabular, e dos vizinhos confinantes, e outros titulares de direitos registrados ou averbados na matrícula.

O dispositivo também traz a exigência da apresentação de certidões negativas da comarca da situação do imóvel e do domicílio do requerente. A apresentação das certidões, tem objetivo de prevenção, caso o imóvel seja objeto de ações judiciais, para que tenha certeza de que o imóvel não tem nenhuma litigiosidade. Vale ressaltar que se as certidões em nome do requerente e cônjuge, obtiver o resultado positivo, há de se examinar que tipo de ação, e se o imóvel é objeto dessa ação, caso contrário não há óbice ao processamento da usucapião pela via extrajudicial. Esse é o entendimento do autor Leonardo Brandelli, "Se as certidões apontarem algumas ações pessoais andamento da usucapião" (BRANDELLI, 2016 p. 81). 
Deverá acompanhar o pedido todos os documentos que provem a origem, a natureza e o tempo e toda cadeia possessória, tais como o pagamento dos impostos e das taxas que incidirem sobre o imóvel. A usucapião ordinária além dos outros requisitos também prevê a necessidade do Justo Título.

Se o imóvel usucapiendo for rural, e estiver enquadrado na faixa de área em que é obrigatório o georreferenciamento, nos termos da lei 10.267/2001, este deverá acompanhar o pedido também.

\subsection{PROCEDIMENTO NO TABELIONATO DE NOTAS}

O processamento da usucapião pela esfera extrajudicial trará reflexos nos tabelionatos de notas, pois é no tabelionato de notas que se iniciará o procedimento. Nesse tópico, abordaremos todo o procedimento que deverá ser realizado pelo tabelião de notas para o processamento da usucapião no registro imóveis.

\subsubsection{LAVRATURA DA ATA NOTARIAL}

O tabelião é dotado de fé pública, e tem prerrogativa de atestar fatos, que vivencia, levando em consideração a sua percepção visual, auditiva, tátil, olfativa. A fé pública do tabelião tem o condão de dar autenticidade a evidências de fatos. $O$ autor Leonardo Brandelli (BRANDELLI, 2016, p 74) conceitua a ata notarial da seguinte forma:

A ata notarial é o instrumento público mediante o qual o notário capta, por seus sentidos, uma determinada situação, um determinado fato, e o translada para seus livros de notas ou para outro documento. É a apreensão de um ato ou fato, pelo notário, e a transcrição dessa percepção em documento próprio.

O artigo 1.071 do novo código de processo civil (BRASIL, 2015), introduziu o art. 216A à lei 6.015/73, vejamos:

Art. 1.071. O Capítulo III do Título V da Lei no 6.015, de 31 de dezembro de 1973 (Lei de Registros Públicos), passa a vigorar acrescida do seguinte art. 216-A: 
Art.

216-

A. Sem prejuízo da via jurisdicional, é admitido o pedido de reconhecimento extrajudicial de usucapião, que será processado

diretamente perante o cartório do registro de imóveis da comarca em que estiver situado o imóvel usucapiendo, a requerimento do interessa do, representado por advogado, instruído com:

I - ata notarial lavrada pelo tabelião, atestando o tempo de posse do requerente e seus antecessores, conforme o caso e suas circunstâncias; (...).

A ata notarial lavrada por tabelião para atestar a posse do requerente, é uma representação da verdade percebida pelo notário, que irá emitir um parecer do que ouviu, viu, presenciou, a respeito do imóvel, sua ocupação, e todas as circunstâncias que forem possíveis de verificar. O tabelião irá lavrar a ata notarial, sem fazer qualquer juízo de valor, pois não cabe a ele esta função, é o registrador que irá fazer a análise, portando o registrador imobiliário não fica vinculado à ata notarial. A ata é um meio de provas a disposição do registrador.

Nesta fase inicial do procedimento da usucapião extrajudicial o notário verificará se há os pressupostos legais para a lavratura da ata, comprovando os requisitos para definir a espécie de Usucapião.

O requerente precisa convencer o tabelião que ele detém a posse no imóvel objeto da usucapião, de forma mansa e pacífica, com animus domini por um lapso de tempo, de forma pública e ininterrupta. Para isso, deve apresentar todos os documentos comprobatórios que possam confirmar essa situação, bem como demostrar como a posse é exercida no imóvel. Para tanto o tabelião, deverá realizar diligência no imóvel para atestar a posse.

O tabelião pode se valer de todos os meios probatórios, realizando diligência in loco, ouvindo testemunhas, com a finalidade de comprovar e atestar se estão presentes os requisitos previstos para a modalidade de usucapião requerida.

Algumas corregedorias da justiça de estados da federação brasileira publicaram provimento dispondo sobre o procedimento da usucapião extrajudicial. Todavia 
algumas dúvidas e divergências de entendimento ainda pairavam sobre a matéria. Entre as dúvidas que surgiram, está qual o conteúdo que a ata notarial deveria conter para ser um meio de prova em que o registrador imobiliário vai se valer ao analisar e processar a usucapião. O artigo 216-A da lei dos registros públicos, elencou como um dos requisitos, a ata notarial lavrada por tabelião atestando o tempo de posse, porém não trouxe mais informações a respeito do conteúdo da ata notarial.

O Conselho Nacional de Justiça (CNJ), solucionou esta questão publicando o provimento $65 / 2017$, que dispõe sobre o processamento da usucapião extrajudicial com abrangência nacional, sanando algumas dúvidas e padronizando os procedimentos para a concretização da lei. O art. 4ํㅡ. I do provimento 65/2017(BRASIL, 2017), dispõe sobre as informações que a ata notarial deve conter, vejamos:

Art. 4ㅇ O requerimento será assinado por advogado ou por defensor público constituído pelo requerente e instruído com os seguintes documentos:

I - ata notarial com a qualificação, endereço eletrônico, domicílio e residência do requerente e respectivo cônjuge ou companheiro, se houver, e do titular do imóvel lançado na matrícula objeto da usucapião que ateste:

a) a descrição do imóvel conforme consta na matrícula do registro em caso de bem individualizado ou a descrição da área em caso de não individualização, devendo ainda constar as características do imóvel, tais como a existência de edificação, de benfeitoria ou de qualquer acessão no imóvel usucapiendo;

b) o tempo e as características da posse do requerente e de seus antecessores;

c) a forma de aquisição da posse do imóvel usucapiendo pela parte requerente;

d) a modalidade de usucapião pretendida e sua base legal ou constitucional;

e) o número de imóveis atingidos pela pretensão aquisitiva e a localização: se estão situados em uma ou em mais circunscrições;

f) o valor do imóvel; 
g) outras informações que o tabelião de notas considere necessárias à instrução do procedimento, tais como depoimentos de testemunhas ou partes confrontantes; (...)

Esse dispositivo do provimento, contribuiu de forma elementar para sanar as questões levantadas nos diferentes estados da federação sobre a ata notarial, pacificando o entendimento em âmbito nacional. Vejamos que o entendimento do conselho nacional de justiça, é que o tabelião formalize em ata notarial os requisitos mais importantes exigidos para a usucapião extrajudicial, para que o registrador imobiliário, já receba uma ata notarial constando os requisitos principais ao processamento.

O provimento menciona no artigo $4^{\circ}$, que a ata deverá conter a descrição do imóvel usucapiendo. Para que o tabelião possa fazer essa descrição na ata, é conveniente que entre os documentos que serão apresentados, esteja a planta e memorial descritivo, para que em diligência, o tabelião possa fazer a conferência da área e demais características do imóvel usucapiendo, podendo para tanto contar com o auxílio de um profissional para a medição.

A ata notarial deverá conter e todos os fatos verificados pelo tabelião, de maneira minuciosa visando sanar qualquer dúvida referente ao período de posse exercida pelo possuidor. Algumas informações são fundamentais para a lavratura da ata notarial. Primeiramente, a qualificação completa do requerente, e do advogado assistente. Informação detalhada da diligência realizada no imóvel, descrevendo as características, benfeitorias existentes.

Também é essencial a descrição dos documentos apresentados ao tabelião que levam a crer que o requerente detém a posse do imóvel, bem como dos documentos de toda a cadeia possessória para computo do tempo se for o caso. Deverá conter informação da certidão imobiliária da matrícula do imóvel, ou a certidão negativa constando que o imóvel não está matriculado no registro de imóveis. Também é necessário a descrição das certidões dos distribuidores, e as informações constante na planta e memorial descritivo. 
Conforme o tipo de usucapião pretendida é necessário a comprovação de justo título. A ata também deverá conter a espécie de usucapião, e valor de mercado do imóvel.

\subsection{PROCESSAMENTO NO REGISTRO DE IMÓVEIS}

O requerente, representado por advogado, deverá apresentar ao registrador de imóveis o requerimento, juntamente com todos os documentos comprobatórios que ensejaram o pedido, para o devido processamento da usucapião extrajudicial que está sendo buscada, e há de se observar o cumprimento dos requisitos legais.

\subsubsection{PRENOTAÇÃO E QUALIFICAÇÃO REGISTRAL}

O primeiro passo para o processamento da usucapião no registro de imóveis é a prenotação, o qual consiste em protocolar o pedido acompanhado dos documentos previstos na lei, no livro de protocolo da serventia registral.

No momento do protocolo não é realizado uma verificação minuciosa dos documentos apresentados. O registrador poderá fazer uma análise superficial para verificar se há algum óbice ao pedido, todavia, não é nessa fase que o registrador vai fazer a qualificação registral, para verificar se os pressupostos estão presentes. Se desta rápida análise for encontrado algum vício, o registrador poderá informar ao advogado, mas não poderá criar óbice ao protocolo, que mesmo sabendo do vício poderá ter o pedido protocolado.

De acordo com a lei $6.015 / 73$, o prazo entre o protocolo e o registro no registro de imóveis deverá ser de até trinta dias. Todavia se tratando do processamento da usucapião extrajudicial, de acordo com o $\S 1^{\circ}$ do artigo 216-A da Lei 6.015/73, esse prazo poderá ser prorrogado até o acolhimento ou rejeição do pedido, pois a previsão para o tempo de processamento deste instituto, ultrapassa os trinta dias.

Após a realização do protocolo dos autos, o registrador irá proceder a autuação, que consiste em analisar todas as páginas do processo, fazendo a numeração e rubricando-as. Depois passará a qualificação registral, que é uma fase elementar no procedimento. Nesse momento irá fazer uma análise jurídica do pedido, verificando 
se estão presentes todos os requisitos previstos na lei, analisando os meios de provas produzidos, verificando se preenche as condições de acordo com o tipo da usucapião.

O artigo $3^{\circ}$ do provimento $n^{\circ}=65 / 2017$ (BRASIL, 2017) do conselho nacional de justiça, padronizou quais informações deverão constar no requerimento deverá ser assinado por advogado ou defensor público, vejamos:

Art. $3^{\circ} \mathrm{O}$ requerimento de reconhecimento extrajudicial da usucapião atenderá, no que couber, aos requisitos da petição inicial, estabelecidos pelo art. 319 do Código de Processo Civil - CPC, bem como indicará:

I - a modalidade de usucapião requerida e sua base legal ou constitucional;'

II - a origem e as características da posse, a existência de edificação, de benfeitoria ou de qualquer acessão no imóvel usucapiendo, com a referência às respectivas datas de ocorrência;

III - o nome e estado civil de todos os possuidores anteriores cujo tempo de posse foi somado ao do requerente para completar o período aquisitivo;

IV - o número da matrícula ou transcrição da área onde se encontra inserido o imóvel usucapiendo ou a informação de que não se encontra matriculado ou transcrito;

V - o valor atribuído ao imóvel usucapiendo.

Dessa forma o registrador ao fazer a qualificação registral deverá observar se essas informações estão presente no requerimento.

Passamos a análise dos requisitos formais para o processamento, de acordo com o artigo 216-A da lei 6.015/73 (BRASIL, 1973):

Art. 216-A. Sem prejuízo da via jurisdicional, é admitido o pedido de reconhecimento extrajudicial de usucapião, que será processado diretamente perante o cartório do registro de imóveis da comarca em que estiver situado o imóvel usucapiendo, a requerimento do interessado, representado por advogado, instruído com: (Incluído pela Lei no 13.105, de 2015) (Vigência)

I - ata notarial lavrada pelo tabelião, atestando o tempo de posse do requerente e de seus antecessores, conforme o caso e suas 
circunstâncias, aplicando-se o disposto no art. 384 da Lei no 13.105, de 16 de março de 2015 (Código de Processo Civil); (Redação dada pela Lei oㅜ 13.465, de 2017)

II - planta e memorial descritivo assinado por profissional legalmente habilitado, com prova de anotação de responsabilidade técnica no respectivo conselho de fiscalização profissional, e pelos titulares de direitos registrados ou averbados na matrícula do imóvel usucapiendo ou na matrícula dos imóveis confinantes; (Redação dada pela Lei no 13.465, de 2017)

III - certidões negativas dos distribuidores da comarca da situação do imóvel e do domicílio do requerente; (Incluído pela Lei oㅜ 13.105, de 2015) (Vigência)

IV - justo título ou quaisquer outros documentos que demonstrem a origem, a continuidade, a natureza e o tempo da posse, tais como o pagamento dos impostos e das taxas que incidirem sobre o imóvel. (Incluído pela Lei no 13.105, de 2015) (Vigência)

$\S 10$ O pedido será autuado pelo registrador, prorrogando-se o prazo da prenotação até o acolhimento ou a rejeição do pedido. (Incluído pela Lei no 13.105, de 2015) (Vigência)

$\S 20$ Se a planta não contiver a assinatura de qualquer um dos titulares de direitos registrados ou averbados na matrícula do imóvel usucapiendo ou na matrícula dos imóveis confinantes, o titular será notificado pelo registrador competente, pessoalmente ou pelo correio com aviso de recebimento, para manifestar consentimento expresso em quinze dias, interpretado o silêncio como concordância.

Após essa qualificação registral, o registrador verificará se estão presentes todos os requisitos, decidindo pelo prosseguimento ou não, do procedimento.

Em caso de faltar algum requisito, o registrador fará nota de exigência, elencando o que precisar ser cumprido para que o requerente possa cumprir para conseguir o processamento no registro de imóveis.

Caso o requerente não concorde com as exigências levantadas pelo registrador, poderá se valer do procedimento de suscitação de dúvida, onde o registrador irá encaminhar os documentos protocolados juntamente com a nota de exigência, para que o juiz decida se a exigência é procedente ou improcedente. 


\subsubsection{JUSTIFICAÇÃO ADMINISTRATIVA}

O registrador não está vinculado às provas constituídas nos documentos comprobatórios, ou mesmo na ata notarial que atesta a posse ou ata notarial com provas testemunhal. Se da documentação que acompanha o requerimento, ainda restar dúvidas, ou não forem suficientes e convincentes, o registrador poderá se valer do procedimento da justificação administrativa o qual o requerente poderá produzir outros meios de provas, como documental, de imagens, testemunhas entre outros. Poderá ainda o registrador realizar diligências no imóvel usucapiendo. Vejamos essa previsão no $§ 15$ do artigo 216-A da Lei 6.015/73 (BRASIL, 1973):

$\S 15$. No caso de ausência ou insuficiência dos documentos de que trata o inciso IV do caput deste artigo, a posse e os demais dados necessários poderão ser comprovados em procedimento de justificação administrativa perante a serventia extrajudicial, que obedecerá, no que couber, ao disposto no $\S 50$ do art. 381 e ao rito previsto nos arts. 382 e 383 da Lei no 13.105, de 16 março de 2015 (Código de Processo Civil). (Incluído pela Lei oㅜ 13.465, de 2017)

Após as provas necessárias serem produzidas, se for o caso, e não restar mais nenhuma dúvida e não houver nenhuma exigência a ser cumprida, o registrador irá para a próxima fase do procedimento.

\subsubsection{NOTIFICAÇÕES}

Com a qualificação registral, o próximo passo é as assinaturas de todos os titulares de direito, e dos vizinhos confrontantes. Havendo todas as assinaturas, o procedimento continua passando para as notificações aos entes públicos. Todavia se se faltar alguma assinatura, o registrador passa para a fase das notificações, que fará pessoalmente, ou por correio com aviso de recebimento, ou ainda por intermédio do Registro de títulos e documentos, que deverão manifestar o consentimento ou impugnação em 15 dias a partir da data que foi notificado, onde o silêncio importa em consentimento.

Podemos observar que o grande avanço desse instituto, está nessa fase, onde a Lei № 13.465, de 2017, alterou o $\S 2^{\circ}$ e o $\S 13^{\circ}$ do artigo 216-A da Lei 6.015/73, trazendo 
a solução ao grande entrave na efetividade do instituto da usucapião extrajudicial, que era a necessidade de manifestação de consentimento.

A nova redação do artigo dispõe que em caso dos titulares de direitos se encontrarem em lugar incerto e não sabido, a notificação prevista se dará por edital publicado em jornal de grande circulação por duas vezes, contando o prazo de quinze dias entre cada edital, e interpretando o silencio como concordância. Passamos à análise do $\S$ $2^{\circ}$ e o $§ 13^{\circ}$ do artigo 216-A da Lei 6.015/73 (BRASIL, 1973):

$\S 20$ Se a planta não contiver a assinatura de qualquer um dos titulares de direitos registrados ou averbados na matrícula do imóvel usucapiendo ou na matrícula dos imóveis confinantes, o titular será notificado pelo registrador competente, pessoalmente ou pelo correio com aviso de recebimento, para manifestar consentimento expresso em quinze dias, interpretado o silêncio como concordância. (Redação dada pela Lei no 13.465, de 2017)

\section{$(\ldots)$}

$\S 13$. Para efeito do $\S 20$ deste artigo, caso não seja encontrado o notificando ou caso ele esteja em lugar incerto ou não sabido, tal fato será certificado pelo registrador, que deverá promover a sua notificação por edital mediante publicação, por duas vezes, em jornal local de grande circulação, pelo prazo de quinze dias cada um, interpretado o silêncio do notificando como concordância. (Incluído pela Lei ํㅜ 13.465, de 2017)

Após o cumprimento das devidas notificações, e havendo impugnação dentro do prazo estipulado pela lei, o oficial registrador poderá notificar o requerente, o advogado e demais interessados para comparecerem na sede da serventia extrajudicial, para participarem de audiência para visando firmar um acordo entre as partes.

Restando frutífera a audiência de conciliação, o registrador, passará para o próximo passo, que é dar ciência aos entes públicos, a União, o Estado, o Município ou Distrito Federal se for o caso.

Se não houver conciliação entre as partes, não será possível o reconhecimento da usucapião pela via extrajudicial, então o registrador fará nota termo relatando a 
impugnação, e o requerente poderá ajuizar ação, adequando o processo ao procedimento comum.

Quando não houver impugnação o oficial registrador dará ciência aos entes públicos, União, Estado, e município ou Distrito Federal se for o caso para manifestação em quinze dias. Há quem defenda que essa notificação para dar ciência aos entes públicos poderá ser concomitante às notificações dos titulares de direitos reais sobre o imóvel, contribuindo para a celeridade do procedimento.

Por fim, após cumprida a notificação dos entes públicos, e não haver manifestação, o oficial deverá publicar edital em jornal de grande circulação, para ciência de terceiros interessados, para manifestação em até quinze dias.

\subsubsection{REGISTRO DA USUCAPIÃO EXTRAJUDICIAL}

Não havendo manifestação de terceiros interessados, e for cumprido as notificações, e não haver impugnação a documentação estiver em conformidade com os requisitos previstos, o oficial registrador registrará a aquisição do imóvel em nome do requerente.

Quando a descrição do imóvel coincidir com a descrição constante na matrícula, não se abrirá nova matrícula, o registro será realizado na mesma matrícula. Nessa situação há uma ruptura com o proprietário anterior, pois a aquisição por usucapião é originaria, todavia não se encerrará a matrícula, em obediência ao histórico do registro.

Já quando a descrição do imóvel não coincidir com a da matrícula, ou se o imóvel ainda não for matriculado no registro de imóveis, se abrirá uma matrícula para realizar o registro do imóvel usucapiendo.

Para a abertura de matrícula há de obedecer aos requisitos essenciais para esse ato, previstos na lei de registros públicos no artigo 176, § 1ํ, II (BRASIL, 1973):

$\S 1^{\circ} \mathrm{A}$ escrituração do Livro oํ 2 obedecerá às seguintes normas: 


\section{$(\ldots)$}

II - são requisitos da matrícula:

1) o número de ordem, que seguirá ao infinito;

2) a data;

3) a identificação do imóvel, que será feita com indicação:(Redação dada pela Lei no 10.267 , de 2001)

a - se rural, do código do imóvel, dos dados constantes do CCIR, da denominação e de suas características, confrontações, localização e área; (Incluída pela Lei № 10.267, de 2001)

b - se urbano, de suas características e confrontações, localização, área, logradouro, número e de sua designação cadastral, se houver. (Incluída pela Lei $n^{\circ} 10.267$, de 2001)

4) o nome, domicílio e nacionalidade do proprietário, bem como:

a) tratando-se de pessoa física, o estado civil, a profissão, o número de inscrição no Cadastro de Pessoas Físicas do Ministério da Fazenda ou do Registro Geral da cédula de identidade, ou à falta deste, sua filiação;

b) tratando-se de pessoa jurídica, a sede social e o número de inscrição no Cadastro Geral de Contribuintes do Ministério da Fazenda;

5) o número do registro anterior;

Após todo trâmite, o processamento da usucapião extrajudicial se encerra com o registro, no livro 02 do registro de imóveis, e tem caráter de aquisição originária da propriedade.

\subsection{DAS CONTRIBUIÇÕES}

O código de processo civil trouxe ao ordenamento jurídico a usucapião pela via extrajudicial. A tendência é que reduza o número desse tipo de ações na justiça, colaborando para que o poder judiciário processe os processos que realmente são litigiosos, e que necessita da tutela jurisdicional. O processamento pela via extrajudicial é uma opção do requerente, que poderá escolher entre o extrajudicial e o judicial. 
Com essa possibilidade a população está sendo beneficiada com a celeridade, pois o procedimento se tornou mais dinâmico. É possível que um procedimento seja concluído em uma faixa de três meses. Nesse aspecto não há dúvidas que esse procedimento, inovou de forma muito positiva o ordenamento jurídico.

Essa previsão também trouxe avanço no sentido de prever todas as espécies de Usucapião serem processadas pelo registrador imobiliário, fazendo com que esse instituto tenha uma generalização a qualquer requerente que preencha os requisitos de qualquer tipo de usucapião.

\section{CONSIDERAÇÕES FINAIS}

Dentre as propostas trazidas pelo novo código de processo civil, o presente artigo abordou com ênfase o instituto da usucapião extrajudicial, como forma de desjudicialização de demandas. Explorou-se o procedimento extrajudicial, as suas fases, e os requisitos previsto na lei, que tem um condão de simplificar os procedimentos, para obter mais celeridade na prestação da tutela jurisdicional.

Verificou-se que os serviços notarias e de registro podem contribuir sobremaneira no processo de desjudicialização, maximizando as vias efetivação dos direitos. Concluiuse que, o procedimento extrajudicial da usucapião contribui de forma elementar para a garantia dos direitos fundamentais, à dignidade da pessoa humana, em especial o direito da propriedade, que é também uma função social, em proveito da coletividade, conforme está previsto no artigo 5ํㅡㄹ inciso XXII da carta Magma.

Da pesquisa doutrinária e legislativa realizada, foi possível observar, a importância de instituto da usucapião ao longo dos anos, e que de acordo com os anseios da sociedade está evoluindo e se adaptando para fazer cumprir a sua função.

Do estudo realizado, analisou-se que o Novo código de Processo Civil inovou trazendo a previsão da usucapião pela via extrajudicial, todavia, a redação original do artigo 1.071 ainda apresentava um óbice a efetividade do instituto, quando previa que o silencio do proprietário tabular, importava em discordância do procedimento. 
Porém esse problema foi solucionado pela entrada em vigor da lei 13.465 de 11 de Julho de 2017, que prevê a notificação por edital em casos que não houver manifestação. Por fim analisou-se que o instituto cumpre a função para qual foi criado.

Identificou-se que outro avanço em termos de regulamentação desse novo instituto, foi a publicação do provimento № 65 de 14/12/2017 pelo conselho nacional de justiça, que regulamentou o procedimento em âmbito nacional, estabelecendo diretrizes para o procedimento da usucapião extrajudicial nos serviços notariais e de registro de imóveis, enfim, padronizando o procedimento e pacificando entendimentos em todo o país.

O instituto da usucapião extrajudicial ainda é muito novo no ordenamento jurídico, mas as evidências indicam que esse instituto vem trazendo efetividade e está cumprindo com o seu objetivo.

\section{REFERÊNCIAS}

BARRUFINI, José Carlos Tosetti. Usucapião Constitucional Urbano e Rural: função social da propriedade. São Paulo: Atlas, 1998.

BRANDELLI, Leonardo. Teoria geral do direito notarial. $2^{\mathrm{a}}$ ed. São Paulo. Saraiva, 2007, p.04.

BRANDELLI, Leonardo. Usucapião Administrativa- De acordo com o Novo Código de Processo Civil. São Paulo: Saraiva, 2016.

BRASIL. Constituição da República Federativa do Brasil de 1988. Disponível em: http://www.planalto.gov.br/ccivil_03/constituicao/constituicaocompilado.htm Acesso em: 16 de Setembro de 2020

. Lei oㅡ 6.015, de 31 de dezembro de 1973. Dispõe sobre os registros públicos, e dá outras providências. Disponível em: http://www.planalto.gov.br/ccivil_03/leis//6015compilada.htm. Acesso em $20 \mathrm{de}$ Setembro 2020 
. Lei oㅜ 9.514, de 20 de novembro de 1997. Dispõe sobre o Sistema de Financiamento Imobiliário, institui a alienação fiduciária de coisa imóvel e dá outras providências.

Disponível em: http://www.planalto.gov.br/Ccivil_03/leis/L9514.htm. Acesso em: 20 de Setembro 2020.

. Lei no 11.441 , de 4 de janeiro de 2007. Altera dispositivos da Lei no 5.869, de 11 de janeiro de 1973 - Código de Processo Civil, possibilitando a realização de inventário, partilha, separação consensual e divórcio consensual por via administrativa. Disponível em: http://www.planalto.gov.br/ccivil_03/_ato20072010/2007/lei/111441.htm. Acesso em: 20 de Setembro 2020.

. Lei $n^{0}$ 10.931, de 02 de agosto de 2004. Disponível em: http://www.planalto.gov.br/ccivil_03/_ato20042006/2004/lei//10.931.htm. Acesso em: 20 de Setembro 2020. . Lei no 10.406 , de 10 de Janeiro de 2.002. Institui o Código Civil. Disponível em: http://www.planalto.gov.br/ccivil_03/leis/2002/110406.htm. Acesso em 16 de Setembro de 2020.

. LEI № 13.465, DE 11 DE JULHO DE 2017. Dispõe sobre a regularização fundiária rural e urbana, sobre a liquidação de créditos concedidos aos assentados da reforma agrária e sobre a regularização fundiária no âmbito da Amazônia Legal, e outros assuntos. Disponível em: http://www.planalto.gov.br/ccivil_03/_ato2015-2018/2017/lei/L13465.htm. Acesso em 18 de Setembro de 2020.

. Lei oํ 13.105, de 16 de Março de 2015. Código de processo civil. Disponível em: http://www.planalto.gov.br/ccivil_03/_ato20152018/2015/lei//13105.htm acesso em 20/09/2020.

Conselho nacional de justiça. Provimento № 65 de 14/12/2017. Estabelece diretrizes para o procedimento da usucapião extrajudicial nos 
serviços notariais e de registro de imóveis. Disponível em: https://atos.cnj.jus.br/atos/detalhar/2527. Acesso em 20/09/2020.

CANOTILHO, J.J. Gomes. Direito constitucional e teoria da constituição. Coimbra: Almedina, 2003

C775j, Justiça em números 2016: ano-base 2015/Conselho Nacional de Justiça Brasília: CNJ, 2016. Anual. Poder Judiciário - estatística - Brasil. II Administração pública - estatística- Brasil. P. 42.Disponível em: http://www.cnj.jus.br/files/conteudo/arquivo/2016/10/b8f46be3dbbff344931a9335799 15488.pdf . Acesso em 20/03/2018.

FARIAS, Cristiano Chaves de; ROSENVALD, Nelson. Direitos Reais. 5. ed. Rio de Janeiro: Lumen, Juris, 2008.

FARIAS; ROSENVALD, Cristiano Chaves de; ROSENVALD, Nelson. Curso de direito civil: Reais. 8 ed. Salvador: JusPodivm, 2012.

GOMES, Orlando. Direitos Reais. 21. ed. Rio de Janeiro: Forense, 2012.

MARINONI, Luiz Guilherme. Garantia da tempestividade da tutela jurisdicional e duplo grau de jurisdição. In: CRUZ E TUCCI, José Rogério. Garantias Constitucionais do processo civil. São Paulo: RT, 1999.

MORAES, Alexandre de. Direitos Humanos Fundamentais. Teoria Geral. Comentários aos arts. $1^{\circ}$ à $5^{\circ}$ da Constituição da República Federativa do Brasil. Doutrina e Jurisprudência. 2. ed. São Paulo: Atlas S.A., 1998.

OLIVEIRA, Daniela Olímpio de. Desjudicialização, acesso à justiça e teoria geral do processo. Curitiba: Juruá, 2014.

PAIVA, João Pedro Lamana. Novo CPC introduz a Usucapião Extrajudicial no país. Instituto de Registro Imobiliário do Brasil. Disponível em: $<$ http://irib.org.br/arquivos/biblioteca/Versa7710_correta_Artigo_Lamana_Paiva_Usu capiao.pdf>. Acesso em: 25 Março 2018. 
RIZZARDO, Arnaldo. Direito das Coisas. 6. ed. Rio de Janeiro: Forense, 2013.

VIANNA, Hélio. História do Brasil: Monarquia e República (Edição comemorativa do Sesquicentenário da Independência). São Paulo: Edições Melhoramentos, 1972. v. III.

Enviado: Agosto, 2020.

Aprovado: Outubro, 2020. 